\title{
Loss of Neuron-Astroglial Interaction Rapidly Induces Protective CNTF Expression after Stroke in Mice
}

\author{
Seong Su Kang, ${ }^{1,2}$ Matthew P. Keasey, ${ }^{1,2}$ Jun Cai, ${ }^{3}$ and Theo Hagg ${ }^{1,2,4}$ \\ ${ }^{1}$ Kentucky Spinal Cord Injury Research Center and Departments of ${ }^{2}$ Neurological Surgery, ${ }^{3}$ Pediatrics, and ${ }^{4}$ Pharmacology and Toxicology, University of \\ Louisville, Louisville, Kentucky 40292
}

\begin{abstract}
Ciliary neurotrophic factor (CNTF) is a potent neural cytokine with very low expression in the CNS, predominantly by astrocytes. CNTF increases rapidly and greatly following traumatic or ischemic injury. Understanding the underlying mechanisms would help to design pharmacological treatments to increase endogenous CNTF levels for neuroprotection. Here, we show that astroglial CNTF expression in the adult mouse striatum is increased twofold within $1 \mathrm{~h}$ and increases up to $>30$-fold over 2 weeks following a focal stroke caused by a transient middle cerebral artery occlusion (MCA0). Selective neuronal loss caused by intrastriatal injection of quinolinic acid resulted in a comparable increase. Cocultured neurons reduced CNTF expression in astrocytes, which was prevented by light trypsinization. RGD (arginine-glycine-aspartic acid) blocking peptides induced CNTF expression, which was dependent on transcription. Astroglial CNTF expression was not affected by diffusible neuronal molecules or by neurotransmitters. The transient ischemia does not seem to directly increase CNTF, as intrastriatal injection of an ischemic solution or exposure of naive mice or cultured cells to severe hypoxia had minimal effects. Inflammatory mechanisms were probably also not involved, as intrastriatal injection of proinflammatory cytokines (IFN $\gamma$, IL6) in naive mice had no or small effects, and anti-inflammatory treatments did not diminish the increase in CNTF after MCA0. CNTF-/mice had more extensive tissue loss and similar astrocyte activation after MCAO than their wild-type littermates. These data suggest that contact-mediated integrin signaling between neurons and astrocytes normally represses CNTF expression and that neuronal dysfunction causes a rapid protective response by the CNS.
\end{abstract}

\section{Introduction}

Ciliary neurotrophic factor $(\mathrm{CNTF})$ can rescue various types of adult CNS neurons in disease models, including striatal (Anderson et al., 1996; Emerich et al., 1997; Zala et al., 2004), cholinergic forebrain (Hagg et al., 1992), dopaminergic midbrain (Hagg and Varon, 1993), and motor neurons (Mitsumoto et al., 1994; Sagot et al., 1995; Pun et al., 2006; Simon et al., 2010). CNTF is also a trophic factor for oligodendrocytes and has protective effects in a multiple sclerosis model (Louis et al., 1993; Linker et al., 2002). Intraocular CNTF is being developed as a treatment for retinal degeneration (Sieving et al., 2006; Emerich and Thanos, 2008). However, delivery of CNTF to the CNS is hampered by limited diffusion across the blood-brain barrier and serious systemic side effects, which caused the failure of clinical trials for amyotrophic lateral sclerosis (Thoenen and Sendtner, 2002). CNTF is almost exclusively produced in the nervous system, and in the CNS expression is very low compared to that in the peripheral

\section{Received Nov. 10, 2011; accepted May 8, 2012.}

Author contributions: S.S.K., M.P.K., J.C., and T.H. designed research; S.S.K., M.P.K., J.C., and T.H. performed research; S.S.K., M.P.K., and T.H. analyzed data; S.S.K., M.P.K., and T.H. wrote the paper.

This work was supported by NIH Grants AG29493, RR031159, and GM103507; Norton Healthcare; and the Commonwealth of Kentucky Challenge for Excellence. We thank Rollie Reid (1972-2011) and Hillary Conway for their excellent technical assistance, and Evelyne Gozal and Roy Sachleban for assistance with the OGD model.

The authors declare no competing financial interests.

Correspondence should be addressed to Dr. Theo Hagg, Kentucky Spinal Cord Injury Research Center, 511 South Floyd Street, MDR Building, Room 616, Louisville, KY 40292. E-mail: theo.hagg@louisville.edu.

DOI:10.1523/JNEUROSCI.1746-12.2012

Copyright $\odot 2012$ the authors $\quad 0270-6474 / 12 / 329277-11 \$ 15.00 / 0$ nerves and is produced mainly by astrocytes (Ip, 1998; Stockli et al., 1989; Park et al., 2000). It follows that pharmacological agents that enter the CNS and stimulate endogenous CNTF production might be neuroprotective. We found that a $\mathrm{D}_{2}$ dopamine agonist, which reduces cAMP, increases CNTF levels twofold in mice and in cultured astrocytes (Yang et al., 2008). However, $\mathrm{D}_{2}$ receptors are not sufficiently widespread to warrant developing $\mathrm{D}_{2}$-based CNTF inducers. A more general mechanism may be found in the response to traumatic brain injury (Ip et al., 1993a; Asada et al., 1995), lens injury (Leibinger et al., 2009), or focal ischemic stroke by middle cerebral artery occlusion (MCAO) (Hu et al., 1997; Lin et al., 1998; Park et al., 2000), after which both mRNA levels and protein show rapid and dramatic increases in astrocytes.

The increase in CNTF seen in the striatum of rats after MCAO (Lin et al., 1998) could theoretically involve several mechanisms, including ischemia, reperfusion injury, inflammation, and neuronal degeneration. Proinflammatory cytokines IL6 (Wang et al., 1995; Clark et al., 1999) and IFN $\gamma$ (de Bilbao et al., 2009) are increased shortly after MCAO in rats, and IFN $\gamma$ can stimulate CNTF expression in cultured astrocytes (Carroll et al., 1993). Neuronal dysfunction as a CNTF inducer following MCAO is also a possibility, as high CNTF expression in astrocytes is suppressed by coculturing with neurons (Rudge et al., 1994). Conversely, the normal in vivo environment of the astrocytes may suppress CNTF to very low levels. If so, neuron-astrocyte interactions could consist of direct cell-to-cell contact or by release of molecules such as neurotransmitters. Identification of the fundamental mechanisms that regulate CNTF would be important for 
rational drug development to treat neurological disorders and would be helpful for investigating CNTF's role in physiological and pathophysiological processes in the CNS.

Here, we investigate the contributions of neuronal interactions, ischemia, and inflammation in the increases in striatal CNTF expression in a mouse MCAO model. We also investigate the potential role of this increase by applying MCAO to CNTF null mice and their littermates.

\section{Materials and Methods}

Animals. A total of 99 male C57BL/6 mice ( $~ 10$ weeks of age; $24-28$ g; The Jackson Laboratory) were used for most of the in vivo studies. FVB (Friend virus B) mice (16 male mice; Jackson Laboratory) were used to compare the effects of quinolinic acid injections, to which these mice are more sensitive than C57BL/6 mice, and stroke. Eight CNTF knock-out mice [VG\#199 in the study by Valenzuela et al. (2003)] and their wildtype littermates were used to determine the potential functions of CNTF following MCAO. Tail snips were collected, and genotyping was performed with the Velocigene protocol provided by Regeneron Pharmaceuticals, who produced the mice. These mice came on a C57BL/6 $\times$ $129 \mathrm{~Sv}$ background and were backcrossed to C57BL/6 five times. In addition, postnatal day 0 ( $\mathrm{P} 0)-\mathrm{P} 1 \mathrm{C} 57 \mathrm{BL} / 6$ mice (Jackson Laboratory) were used to obtain cells for tissue culture experiments. Anesthesia was achieved by an intraperitoneal injection of Avertin $(0.4 \mathrm{mg} 2,2,2-$ tribromoethanol in $0.02 \mathrm{ml}$ of $1.25 \%$ 2-methyl-2-butanol in saline per gram body weight; Sigma-Aldrich). To reduce pain after surgeries, the mice were injected subcutaneously with buprenorphine ( $0.1 \mathrm{ml}$ of a 1:20 dilution of $0.3 \mathrm{mg} / \mathrm{ml}$ stock solution in saline; Ben Venue Laboratories) once they recovered from anesthesia to prevent fatal interaction with Avertin. Injections were given every $12 \mathrm{~h}$ for a total of four injections. To reduce infections, gentamicin was given subcutaneously during surgery, as well as at 2 and $4 \mathrm{~d}$ after surgery $(0.1 \mathrm{ml}$ of a 1:200 dilution of a 40 $\mathrm{mg} / \mathrm{ml}$ stock solution in saline; ButlerSchein). All experiments involving living animals were performed according to University of Louisville Institutional Animal Care and Use Committee protocols and $\mathrm{NIH}$ guidelines.

MCAO focal ischemia model. A unilateral focal ischemic lesion of the striatum and overlying cortex was achieved by a 15 min MCAO. After a midline skin incision in the anterior neck area, the left external carotid artery was exposed and ligated with 5-0 silk suture after small artery branches cauterized (electrocautery; N.S. 237; Codman and Shurtleff). The right common carotid artery and the internal carotid artery were temporarily occluded by microvascular clips, and a small hole was made in the external carotid artery. A 0.21-mm-diameter nylon suture (6021PK5Re; Doccol) was inserted through the hole and advanced to the origin of the middle cerebral artery, approximately over an $8-9 \mathrm{~mm}$ distance. Cerebral blood flow decreased immediately to $\sim 20 \%$ of baseline as measured by a needle probe of laser-Doppler flowmetry (Moor VMS-LDF, VP10M200ST, P10d; Moor Instruments) glued directly on the superior portion of the temporal bone. After $15 \mathrm{~min}$, the Doccol suture was withdrawn and the clips removed from the carotid to restore blood flow to the occluded territory. Sham-operated mice received the same surgery except the filament was not inserted. Afterward, the wound was closed in layers. Body temperature was maintained at $37.0 \pm 0.5^{\circ} \mathrm{C}$ by placing each mouse on a heating pad during surgery and the recovery period. At various times between $1 \mathrm{~h}$ and $14 \mathrm{~d}$, the mice were processed to collect striatal tissue. To test whether inflammation might regulate CNTF expression, some groups of mice received anti-inflammatory drugs injected intraperitoneally daily, starting $1 \mathrm{~d}$ after MCAO, to circumvent their potential neuroprotective actions, until $7 \mathrm{~d}$ after injury. The daily doses were $50 \mathrm{mg} / \mathrm{kg}$ for minocycline (Weng and Kriz, 2007), $5 \mathrm{mg} / \mathrm{kg}$ for indomethacine (Veltkamp et al., 2002), and $50 \mathrm{mg} / \mathrm{kg}$ for ketoprofen (Pinardi et al., 2003).

In a separate experiment, $C N T F-/-$ mice and their wild-type littermates received a $30 \mathrm{~min} \mathrm{MCAO}$. These mice received intensive care by daily replacement of lost weight with a subcutaneous injection of Ringer's lactate-dextrose solution. A hydration gel pack and peanut butter cookies were placed on the bedding in addition to their water bottle and chow. These mice were processed for histology after $14 \mathrm{~d}$.

Intracerebral injections. To inject reagents into the striatum, the heads of the mice were stabilized in a Kopf stereotaxic apparatus, using rat ear bars and a mouse tooth bar set at $0 \mathrm{~mm}$. A burr hole was drilled with a 1 $\mathrm{mm}$ drill bit attached to a Dremel drill at coordinates $1 \mathrm{~mm}$ rostrocaudal and $1.5 \mathrm{~mm}$ lateral from Bregma using the tip of the needle of a $10 \mu \mathrm{l}$ Hamilton syringe clamped into an electrode holder of a Kopf stereotaxic micromanipulator as the probe. Next, the needle was lowered to $3.5 \mathrm{~mm}$ dorsoventral from the dura into the middle of the striatum. After waiting 2 min to ensure adhesion of brain tissue to the needle, which prevents backflow, $1 \mu \mathrm{l}$ of the test reagent was injected over a $3 \mathrm{~min}$ period, followed by another 2 min waiting period, again to prevent backflow. Mice were injected with (1) vehicles specific to the various reagents; (2) $30 \mathrm{nmol}$ quinolinic acid dissolved in saline to selectively kill the striatal neurons, using FVB mice, which are much more sensitive to the striatal excitotoxicity than C57BL/6 mice (Schauwecker, 2005); (3) $1 \mu \mathrm{g}$ each of the proinflammatory cytokines IFN $\gamma$ or IL6 (Prospec), to test the potential CNTF-regulating effects of inflammatory cytokines, or rhCNTF (a gift from Scios Nova); or (4) ischemic solution (Yao et al., 2007) consisting of a mixture of molecules and at an osmolarity and $\mathrm{pH}$ that mimic the ischemic extracellular environment of the stroke tissue (except the low oxygen content) to test whether metabolic components of stroke potentially might contribute to early increased CNTF. Afterward, the needle was withdrawn, any bleeding stopped, and the skin sutured closed. After various times, from $1 \mathrm{~h}$ to $1 \mathrm{~d}$ depending on the injected reagent, the mice were processed to collect striatal tissues.

Whole-body hypoxia. To test the possibility that low oxygen might be responsible for the stroke-induce increases in CNTF, naive C57BL/6 mice were exposed to hypoxia by stepwise decline from sublethal to lethal dosage, comparing them with those age-matched mice housed in room air. Mice experiencing 5\% for lethal hypoxia can rarely survive for $>12$ min (Zhang et al., 2004). In this study, five male adult mice were initially kept under $7 \% \mathrm{O}_{2}$ for $15 \mathrm{~min}$, followed by $6 \% \mathrm{O}_{2}$ for $5 \mathrm{~min}$, and then maintained at $5 \% \mathrm{O}_{2}$ for 10 min during the daylight in environmental chambers (Oxycycler model A84XOV; BioSpherix). The nadir of the ambient oxygen level in the chamber was continuously measured with an oxygen sensor and periodically calibrated via another oxygen analyzer placed at the cage bottom. Humidity (40-50\%), ambient $\mathrm{CO}_{2}$ $(<0.03 \%)$, and temperature $\left(26^{\circ} \mathrm{C}\right)$ in the chambers were periodically monitored and maintained during exposures. Mice were euthanized for brain extraction in $2 \mathrm{~h}$ after exposure.

Tissue cultures. Cells were grown at $37^{\circ} \mathrm{C}$ in an atmosphere containing $5 \% \mathrm{CO}_{2} / 95 \%$ air. Mouse astrocyte cultures were prepared as described previously (Carroll et al., 1993) with some modifications. P0-P1 C57BL/6 mice were decapitated, and their brains were removed and cortices isolated in ice-cold HBSS (Invitrogen). Cortices were dissociated in $0.25 \%$ trypsin-EDTA for $15 \mathrm{~min}$ (Invitrogen) followed by washes in culturing medium comprising DMEM with $10 \%$ fetal calf serum (v/v), 2 mM L-glutamine, $100 \mu \mathrm{g} / \mathrm{ml}$ penicillin, and $100 \mathrm{U} / \mathrm{ml}$ streptomycin. Tissue was triturated in culture medium and left for 5 min to allow undissociated tissue to settle. The cell suspension was transferred to a fresh 50 $\mathrm{ml}$ tube then centrifuged before the cell pellet was resuspended in culturing medium and plated on $10 \mathrm{~cm}$ dishes (Corning). The following day, plates were agitated by hand and washed with PBS (Invitrogen) to remove dead cells and neurons before being returned to fresh culturing medium. Medium was replaced every $3 \mathrm{~d}$ thereafter. When cells were $\sim 90 \%$ confluent, cytosine arabinoside (10 $\mu \mathrm{M}$, Sigma) was added to the culture medium for $3 \mathrm{~d}$ to suppress fibroblast growth. Cultures were maintained for an additional 6-7 d before cells were removed in trypsin $(0.25 \%)$ and plated onto poly-D-lysine-coated ( $50 \mu \mathrm{g} / \mathrm{ml}$; Sigma) six-well plates or transwell membranes $(0.4 \mu \mathrm{m}$ pore size; Corning) at 60,000 cells/ml and grown for an additional 5-6 d before experiments were performed.

Primary mouse neuron cultures were prepared from P0-P1 C57BL/6 mice as follows. Cortices were isolated and trypsinized in $100 \mathrm{U}$ papain latex (Worthington) in dissociation medium $\left[80 \mathrm{mM} \mathrm{Na}_{2} \mathrm{SO}_{4}, 30 \mathrm{~mm}\right.$ $\mathrm{K}_{2} \mathrm{SO}_{4}, 15.8 \mathrm{~mm} \mathrm{MgCl}, 0.25 \mathrm{~mm} \mathrm{CaCl}_{2}, 1 \mathrm{~mm}$ HEPES, $20 \mathrm{~mm}$ glucose, $0.001 \%$ phenol red (v/v), and $1 \mathrm{~mm}$ kynurenic acid, all obtained from 
Sigma]. Neurons were plated onto 5-7 DIV astrocyte cultures or poly-Dlysine-coated plates in Eagle's basal medium supplemented with $10 \%$ heat-inactivated bovine calf serum (BCS; HyClone), $35 \mathrm{~mm}$ glucose, 1 mM L-glutamine, 100 units $/ \mathrm{ml}$ penicillin, and $100 \mu \mathrm{g} / \mathrm{ml}$ streptomycin. After $4 \mathrm{~h}$, the medium was gently removed and cells washed in HBSS before being returned to a 0\% serum medium [Basal Medium Eagle supplemented with 10\% Ham's F-12 (Invitrogen), 1× N2 supplement, $35 \mathrm{~mm}$ glucose, $1 \mathrm{~mm}$ L-glutamine, $100 \mathrm{units} / \mathrm{ml}$ penicillin, and $100 \mu \mathrm{g} / \mathrm{ml}$ streptomycin] to reduce proliferation of dividing cells. Transwell inserts were washed in PBS before being placed on to neuron-enriched cultures at 2-3 DIV, and RNA was isolated $24 \mathrm{~h}$ later. Neuron-astrocyte cocultures were incubated with glutamate $(20 \mu \mathrm{M})$, NMDA antagonist MK$801(50 \mu \mathrm{M})$, dopamine $\mathrm{HCl}(100 \mu \mathrm{M})$, acetylcholine (50 $\mu \mathrm{M})$, and GABA $(100 \mu \mathrm{M})$, all purchased from Sigma, for $6 \mathrm{~h}$ before RNA was isolated. For experiments involving trypsin, culturing medium was removed and stocked before cells were washed in warm HBSS then incubated with trypsin $(0.005 \%)$ in HBSS for 10 min. Trypsin was aspirated and cultures washed with warmed plating medium containing BCS (see above) before being returned to stocked conditioned medium. Control cultures underwent washing but were returned to stocked medium with no further treatment. Cells were lysed after $6 \mathrm{~h}$ and RNA collected.

Cell lines. C6 astroglioma cells (ATCC) were maintained in 75 culture flasks (USA Scientific) in DMEM supplemented with 10\% FCS, $1 \mathrm{~mm}$ L-glutamine, $100 \mathrm{U} / \mathrm{ml}$ penicillin, and $0.1 \mathrm{mg} / \mathrm{ml}$ streptomycin (all from Invitrogen). Cells were washed in PBS and then incubated in $0.05 \%$ trypsin/HBSS. When cells were in suspension, a volume of culture medium equal to that of trypsin/HBSS was added and gently mixed to inactivate trypsin. Cell suspensions were centrifuged at $1200 \mathrm{rpm}$ for 5 min and the supernatant aspirated. Cell pellets were resuspended in fresh culture medium and counted with a hemocytometer according to the manufacturer's instructions (Hausser Scientific).

To determine whether integrins played a role in CNTF regulation, C6 cells were incubated for $24 \mathrm{~h}$ after plating at 160,000 cells/ml. Integrinblocking peptides argenine-glycine-aspartate-serine [RGDS; $20 \mu \mathrm{g} / \mathrm{ml}$ (Panetti and McKeown-Longo, 1993; Droppelmann et al., 2009); catalog \#3498, Tocris Bioscience] or argenine-glycine-glutamate-serine [RGES; $20 \mu \mathrm{g} / \mathrm{ml}$ (Panetti and McKeown-Longo, 1993); catalog \#A5686, Sigma] were added to the culture medium. To test the role of transcription in CNTF regulation, integrin peptide-treated C6 cells were pretreated with the inhibitor of transcription actinomysin $(0.3 \mu \mathrm{g} / \mathrm{ml}$; catalog \#1229, Tocris Bioscience) for $1 \mathrm{~h}$ before addition of peptides. Cells were maintained with peptides for $4 \mathrm{~h}$ before RNA was isolated and CNTF expression quantitated by quantitative reverse-transcription PCR (RT-qPCR).

Oxygen and glucose deprivation (OGD) was performed as described previously (Véga et al., 2006) but was, briefly, performed as follows. C6 cells were plated at 60,000 per milliliter and grown for $24 \mathrm{~h}$ before medium was stocked and cells were washed in DMEM without glucose (Sigma) with supplements ( $1 \mathrm{~mm} \mathrm{L-glutamine,} 100 \mathrm{U} / \mathrm{ml}$ penicillin, $0.1 \mathrm{mg} / \mathrm{ml}$ streptomycin). Cultures were then incubated in a computer-driven hypoxia chamber (Biospherix) with a sensor to measure the dissolved $\mathrm{O}_{2}$ profile. OGD was sustained for 2 or $4 \mathrm{~h}$ of a $24 \mathrm{~h}$ period before stocked medium was returned and cells allowed to recover for 22 or $20 \mathrm{~h}$, respectively. Cells were lysed, RNA extracted, and CNTF measured by RT-qPCR.

$q P C R$. RNA was isolated from cultured cells or from freshly dissected striatum obtained from 1-mm-thick slices after euthanizing mice and quickly dissecting out the brains. After mRNA was extracted by an mRNA kit (74104; Qiagen), cDNA was made at $70^{\circ} \mathrm{C}$ for $5 \mathrm{~min}$ and $37^{\circ} \mathrm{C}$ for $1 \mathrm{~h}$ with $1.0 \mu \mathrm{l}$ total RNA $(1.0 \mu \mathrm{g}), 1.0 \mu \mathrm{l}$ of $500 \mathrm{ng} / \mu \mathrm{l}$ random primers (C118A; Promega), $1.25 \mu \mathrm{l}$ of $10 \mathrm{~mm}$ dNTP mix (U151A; Promega), $5 \mu \mathrm{l} 5 \times$ RT buffer, $1.75 \mu \mathrm{l}$ of RNase-free water, and $1 \mu \mathrm{l}$ of 200U/ $\mu$ l MMLV-RT (M170A; Promega). qPCR was performed at this condition $\left(10 \mathrm{~min}\right.$ at $95^{\circ}$ followed by 40 cycles of $95^{\circ}$ for $15 \mathrm{~s}$ and $60^{\circ}$ for 1 min) using TaqMan Gene Expression Master Mix kits (4369016; Applied Biosystems) and specific primer sets (CNTF, mM00446373_m1 FAM; GAPDH, 4352339E VIC; Applied Biosystems) in an ABI 7900 Thermal Cycler (Applied Biosystems). We used the $\Delta \Delta \mathrm{CT}$ method to calculate changes compared to control vehicle-injected or sham-operated mice.

Histological analyses. To confirm that the quinolinic acid injections caused a similar extent of neuronal injury as the $15 \mathrm{~min} \mathrm{MCAO}$, some mice were
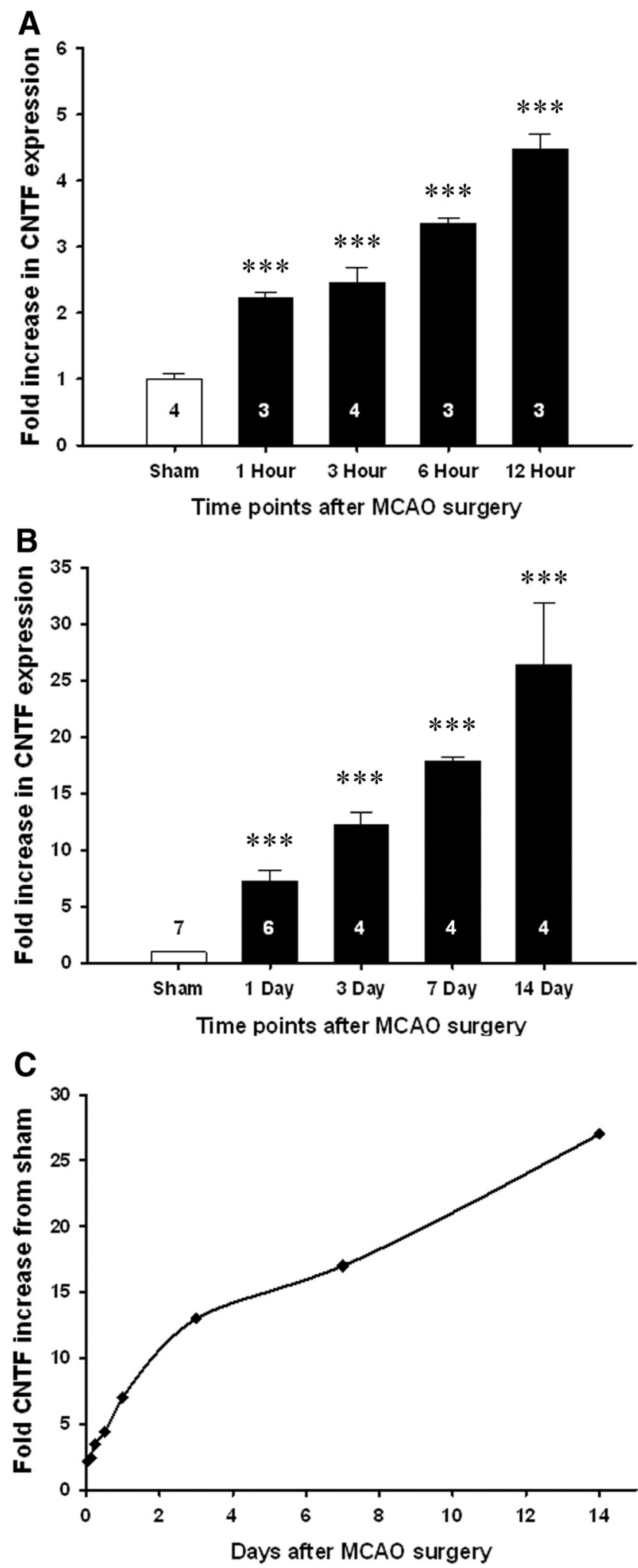

Figure 1. Striatal CNTF expression is increased very rapidly after MCA0 in C57BL/6 mice. $A$, Compared to sham-operated C57BL/6 mice, CNTF expression in the striatum increased as much as twofold within $1 \mathrm{~h}$ following MCAO. B, The rapid increase continued over the next 2 weeks. $C$, The rate of increase was greatest over the first day, as shown by the data from $\boldsymbol{A}$ and $\boldsymbol{B}$ plotted on a linear time scale. Data are shown as the average + SEM. Group sizes are indicated on the columns. ${ }^{* * *} p<0.001$. 
perfused with ice-cold PBS followed by $4 \%$ paraformaldehyde in phosphate buffer. Their brains were collected and postfixed overnight and then cryoprotected in $30 \%$ sucrose overnight, and then $30 \mu \mathrm{m}$ coronal sections were cut on a freezing sliding microtome. Sections through the striatum were stained with cresyl violet. To determine whether the lack of endogenous CNTF would affect tissue loss and astrogliosis, every sixth brain section through the injured striatum from $\mathrm{CNTF}-/$ - mice and their wild-type littermates was immunostained using rabbit antiGFAP primary antibodies (1:1000; AB5804; Millipore) and Alexa fluor 488-conjugated goat anti-rabbit secondary antibodies (1:500; A11008 Invitrogen). To detect those cells that would express CNTF following stroke, sections through the injured striatum were stained with chicken antibodies against $\beta$-galactosidase (1:500; Ab28951; Abcam) and rabbit anti-GFAP (1:1000; AB5804; Millipore), with appropriate fluorescent secondary antibodies.

Statistical analyses. Statistical analyses were performed with one-way ANOVA with Dunnett post hoc tests or, if two groups were compared, with the Student's $t$ test using Excel software (Microsoft). A value of $p<0.05$ was considered to be statistically significant.

\section{Results}

Rapid and large increases in CNTF expression after a 15 min $M C A O$

A 15 min MCAO resulted in a large injury throughout most of the striatum and in a small region of the overlying cortex (data not shown). Striatal CNTF expression was already increased more than twofold $1 \mathrm{~h}$ after the MCAO and increased steadily up to $24 \mathrm{~h}$, when it was approximately sevenfold compared to the values obtained from sham-operated mice (both $p<0.001$; Fig. $1 A, B)$. The increase progressed to $\sim 13$ fold after $3 \mathrm{~d}$ to $\sim 30$-fold after $14 \mathrm{~d}$ (all $p<0.001)$. The slope of the increase was greatest over the first $24 \mathrm{~h}$, whereas the rate of increase leveled off between 3 and $14 \mathrm{~d}$ (Fig. 1C).

\section{Stroke-induced CNTF expression is in astrocytes}

To determine which cells expressed CNTF following the MCAO, we stained sections through the injury site with antibodies against $\beta$-gal in heterozygous CNTF reporter mice. Essentially all $\beta$-gal-positive cells also had GFAP-positive processes as shown by confocal microscopy (Fig. 2). The number of $\beta$-gal-positive cells was much lower than the number of GFAP-positive astrocytes, suggesting that only a subset of cells express enough CNTF to be clearly detectable. The distribution of $\beta$-gal-positive cells was distributed evenly throughout the striatal injury site at $1 \mathrm{~d}$ following MCAO and was predominant in the dense glial network in the injury penumbra at $14 \mathrm{~d}$ (Fig. 3).
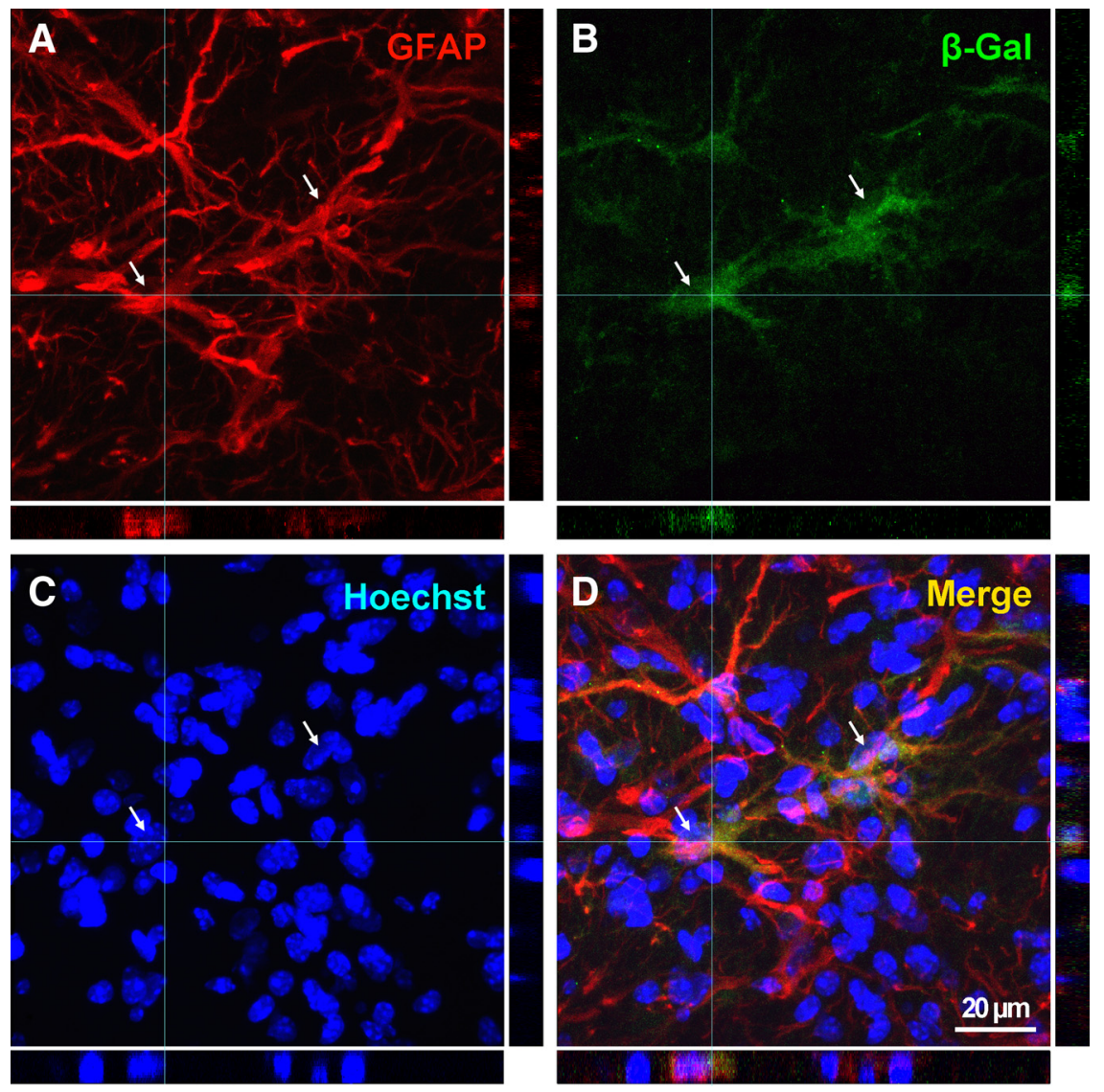

Figure 2. $A-D, C N T F$ expression is seen exclusively in astrocytes after MCAO. A confocal image of a volume-rendered 8.4- $\mu \mathrm{m}$ thick $z$-stack and the $X$ and $Y$ projections showing complete colocalization between the $\beta$-gal product of the CNTF reporter gene in heterozygous CNTF mice and the astroglial process marker GFAP. The image was taken in the striatal penumbra, $14 \mathrm{~d}$ following a 15 min MCA0. Hoechst staining was used to identify the nuclei. Two nuclei of $\beta$-gal-positive cells are indicated by arrows in each panel.
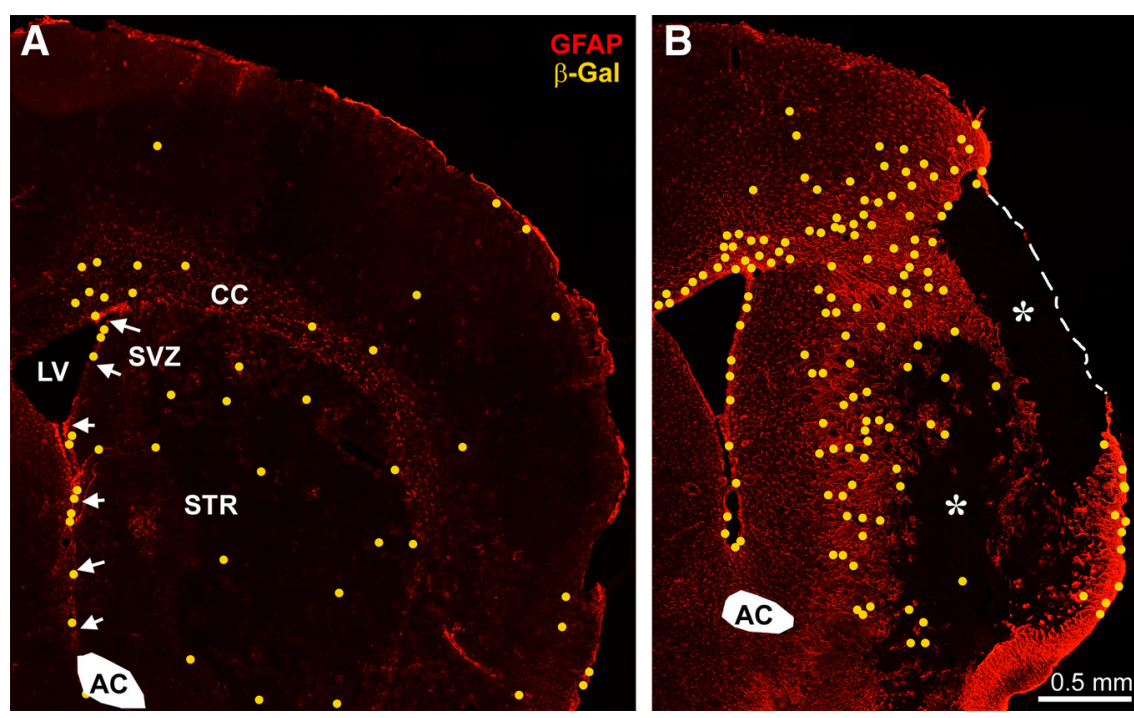

Figure 3. CNTF is expressed throughout the acute injury site and in the chronic penumbral gliotic area after MCA0. Sections are from heterozygous $\beta$-gal CNTF reporter mice. $\beta$-gal-positive cells were plotted as yellow dots onto an image of GFAP staining within the same section because they were too faint to see at this low magnification. Note that the number of $\beta$-gal-positive cells is much lower than that of GFAP-stained cells. A, At $1 \mathrm{~d}$ following MCA0, newly $\beta$-gal-expressing cells are distributed evenly throughout the injured striatum, and there are fewer in the cortex. $B, A t 14 \mathrm{~d}$, the $\beta$-gal-positive cells are predominantly in the injury penumbra, and the core (asterisks) of the injured tissue is devoid of GFAP or $\beta$-gal cells. AC, Anterior commissure; $C$, corpus callosum; LV, lateral ventricle; STR, striatum. Arrows point to the subventricular zone (SVZ). 
A clear GFAP-negative area indicated that astrocytes also died in the core of the injury. There were no $\beta$-gal-positive cells in this core. As Yang et al. (2008) reported previously, staining was also seen in the subventricular zone astrocytes both on the injured and uninjured side.

\section{Selective neuronal degeneration causes similar CNTF increases as $M C A O$}

The finding that the most rapid phase of the CNTF increase after $\mathrm{MCAO}$ was seen over the first $24 \mathrm{~h}$ suggested that neuronal degeneration might be responsible for the increase. Therefore, FVB mice received intrastriatal injections with quinolinic acid, which resulted in extensive loss of striatal neurons after $4 \mathrm{~d}$ (Fig. $4 \mathrm{~A}$ ). We used FVB mice, as C57BL/6 mice are much less or inconsistently susceptible to quinolinic acid-induced neuronal death (Schauwecker, 2005) (T. Hagg, unpublished observation). Neuronal death is progressive and is largely complete by $4 \mathrm{~d}$ after quinolinic acid injury. The increase in striatal CNTF expression in these mice was of a similar magnitude as that seen $1 \mathrm{~d}$ following a 15 min MCAO in FVB mice (Fig. 4C), when neurons are also clearly lost (Fig. $4 B$ ). The $\sim 2.5$-fold increase in CNTF in FVB mice in response to the $\mathrm{MCAO}$ is lower than the approximately sevenfold change seen in C57BL/6 mice, which is most likely due to strain differences.

\section{Neuronal contact downregulates CNTF expression in vitro}

To confirm that cocultured neurons cause a decrease in CNTF expression, primary cortical neurons were seeded on astrocyte monolayers. CNTF expression was much lower in cocultures than in pure astrocyte cultures as measured by qPCR (Fig. $5 A$ ). We next tested whether neuronal contact or soluble molecules from neurons were responsible for the decrease in astroglial CNTF. First, neuron-astrocyte cocultures were treated with $0.005 \%$ trypsin to disrupt intercellular contact of proteins, which caused a $1.47 \pm 0.13$-fold (SEM; $p<0.05)$ increase in CNTF expression after $6 \mathrm{~h}$ (Fig. $5 B$ ) with no visible loss of neurons or astrocytes (data not shown). To exclude the possibility that soluble agents were involved in the neuronal repression of CNTF, neuronal conditioned media was added to pure astroglial cultures, which did not affect the levels of CNTF expression (Fig. $5 C$ ). Moreover, cocultures of neurons and astrocytes separated by a semipermeable membrane in Boyden chambers also did not affect astroglial CNTF expression (Fig. 5D). Though these experiments rule out many diffusible factors, they do not address the possibility that neurotransmitters may be released at synapses and thus do not diffuse over longer distances. We therefore tested whether several neurotransmitters prevalent in the striatum would affect CNTF in cocultures. However, glutamate, acetylcholine, and GABA did not affect CNTF expression (Fig. 5E). To test the possibility that endogenous glutamate could play a role in regulating $\mathrm{CNTF}$, the NMDA antagonist MK-801 was added to the culture, but was also without a significant effect (Fig. 5E). As a control, dopamine caused a decrease in CNTF expression to $0.33 \pm 0.06$-fold of control $(p<0.01)$ in cocultures (Fig. $5 E$ ) (Rudge et al., 1994; Nagao et al., 1995). These data suggested that soluble factors and neurotransmitters play no role or a very limited role in the regulation of CNTF. We therefore investigated the possibility of contact-mediated CNTF repression through integrins. Incubation of C6 cells with integrin-blocking RGDS peptide induced CNTF expression $1.62 \pm 0.17$-fold seen with the inactive control RGES peptide (Fig. $5 F$ ). RGDS peptide-mediated CNTF induction was abolished by pretreatment of cells with the transcriptional blocker actinomysin. Together, these data suggest that contact through integrin signaling suppresses CNTF expression
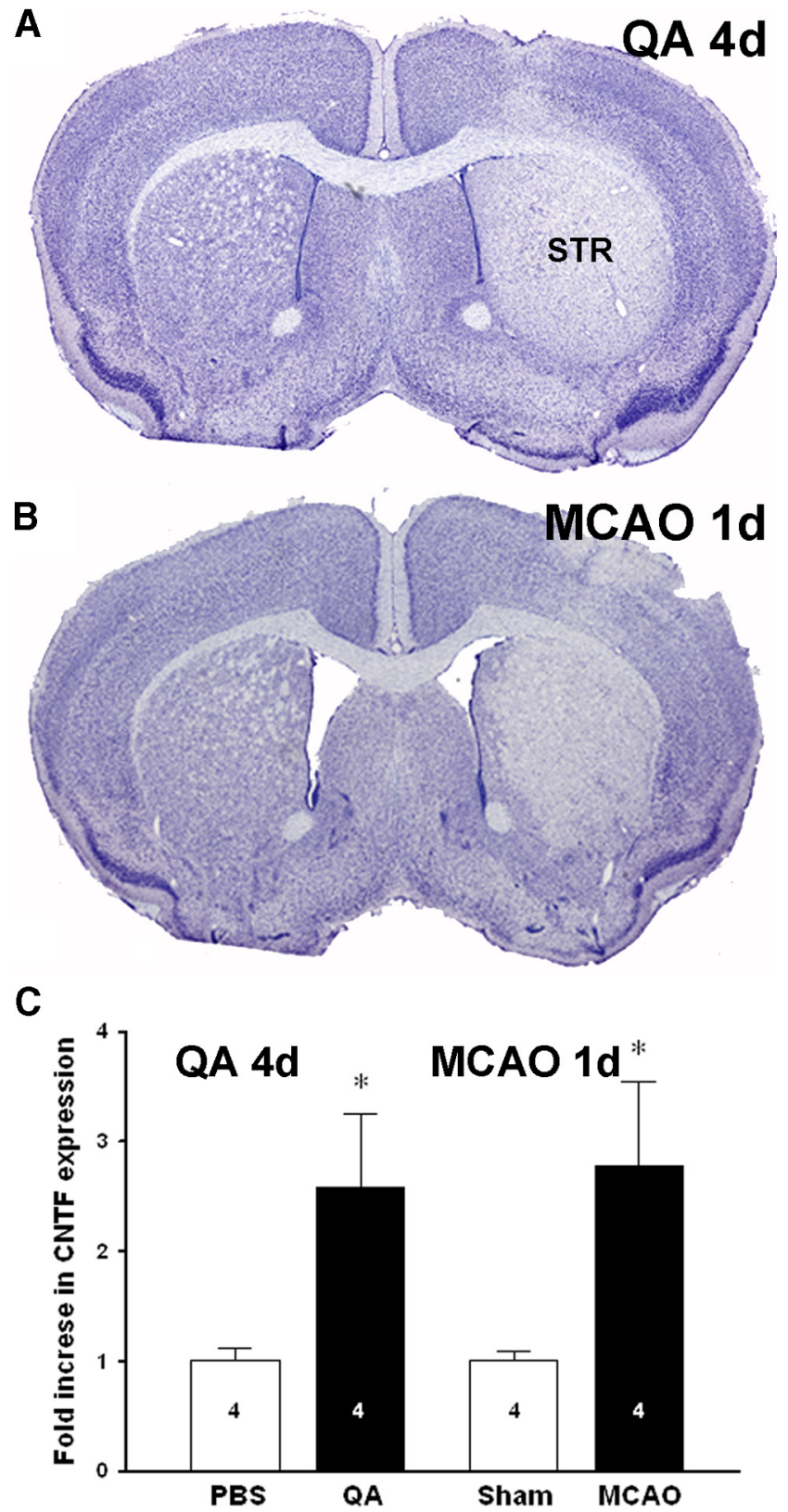

Figure 4. A neuron-selective quinolinic acid lesion causes similar increases in CNTF expression as an MCAO in FVB mice. $A$, As expected, intrastriatal injection of quinolinic acid (QA) in FVB mice caused an almost complete loss of striatal neurons after $4 \mathrm{~d}$, as shown in cresyl violet-stained sections. $\boldsymbol{B}$, Ischemic injury $1 \mathrm{~d}$ after MCAO in FVB mice caused injury to a similar area of the striatum (STR). C, CNTF expression was increased to the same extent after QA and MCAO injury. Group sizes are indicated in the columns. Data are shown as the average + SEM. ${ }^{*} p<0.05$.

and that CNTF induction upon integrin blockade occurs at the transcriptional level, i.e., requires RNA polymerase II activity.

Ischemic conditions minimally affect CNTF expression Others have developed an ischemic solution mimicking the metabolic conditions of an ischemic stroke and have shown its utility as an experimental tool (Yao et al., 2007). Among the main ingredients are glutamate, glucose, and a $\mathrm{pH}$ of 6.4. Injection of this ischemic solution into the striatum of naive mice increased CNTF levels by only $18 \%$ by $1 \mathrm{~h}$ (Fig. 6A), compared to the $\sim 230 \%$ seen $1 \mathrm{~h}$ after MCAO (Fig. $1 A$ ). To test whether the hypoxic conditions of the MCAO might be involved in the rapid 

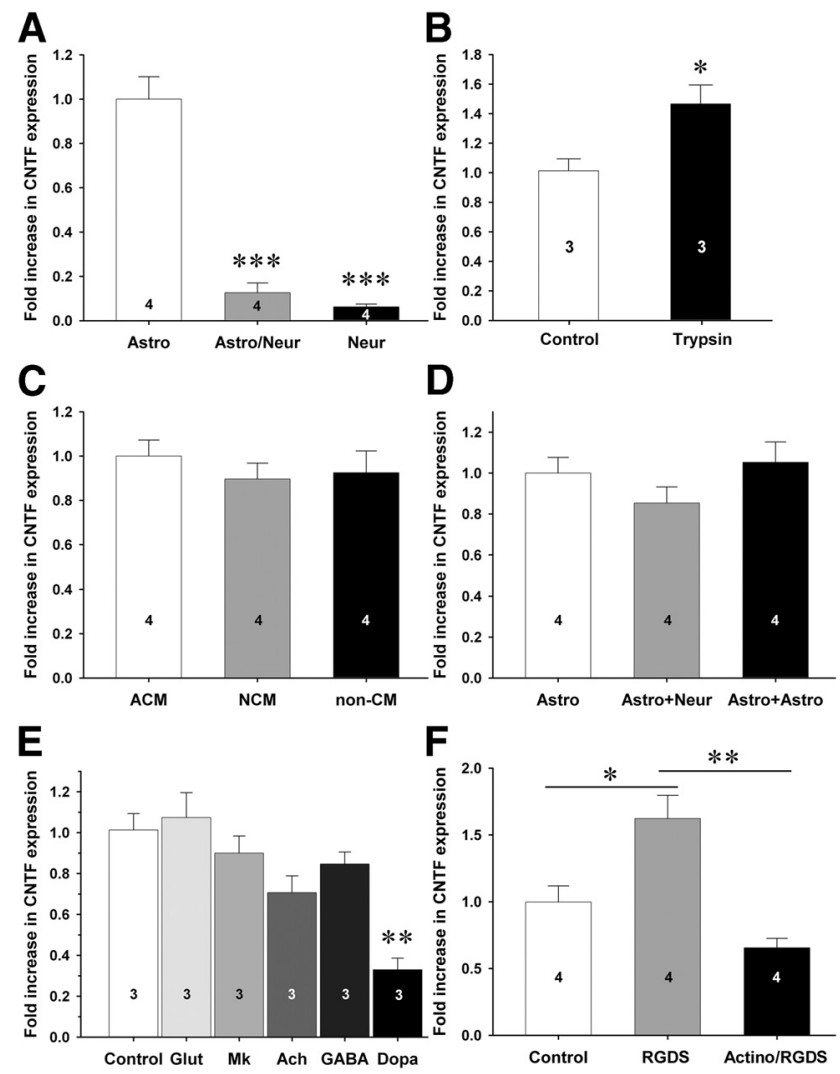

Figure 5. Neuronal contact decreases CNTF expression in cultured astrocytes. $\boldsymbol{A}$, When cocultured with neurons, astrocytes dramatically decrease their CNTF expression. Neurons themselves have very low levels of CNTF. $\boldsymbol{B}$, When neuron-astrocyte cocultures are treated with a low concentration of trypsin to degrade membrane and extracellular proteins, CNTF levels increase within $6 \mathrm{~h}$. $C$, Conditioned media from astrocytes (ACM) or neurons (NCM) do not affect CNTF expression levels in astrocytes compared to nonconditioned media (non-CM). D, CNTF levels are not decreased in astrocytes that are cocultured with neurons in compartmentalized Boyden chambers. The third column represents an astrocyte-astrocyte coculture as a control. $\boldsymbol{E}$, The neurotransmitters glutamate (Glut), acetylcholine (Ach), and GABA do not affect CNTF expression in cultured astrocytes. As expected, and as a positive control, dopamine (Dopa) decreases CNTF expression. Endogenous NMDA receptors are also not involved in CNTF regulation as shown by the MK-801 NMDA antagonist (Mk). F, (6 astroglioma cells were incubated with or without the transcriptional inhibitor actinomysin (actino) for $1 \mathrm{~h}$ before incubation with an integrin blocking RGDS peptide for $4 \mathrm{~h}$ before RNA was isolated and CNTF expression quantitated by qPCR. Control is an inactive RGES peptide. All data represent three to four individual experiments with multiple wells per condition per experiment. Data are shown as the average + SEM. ${ }^{*} p<0.05 ;{ }^{* *} p<0.01 ;{ }^{* * *} p<0.001$.

CNTF increases, we exposed naive mice to severe hypoxia (decreasing oxygen levels to a minimum of $5 \%$ for $10 \mathrm{~min}$ ). CNTF expression levels in the striatum were unaffected (Fig. 6B). Finally, C6 cells were exposed to different severities of oxygenglucose deprivation, an accepted in vitro model for ischemia (Goldberg and Choi, 1993). CNTF levels were not significantly increased after $4 \mathrm{~h}$ OGD (Fig. 6C). Cultured C6 cells can produce CNTF (Meyer and Unsicker, 1994) and increase production after mechanical trauma (M. P. Keasey and T. Hagg, unpublished observation).

Inflammation has little effect on CNTF levels following MCAO

To test whether inflammation might have contributed to the stroke-induced increases in CNTF, we injected the inflammatory cytokines IFN $\gamma$ and IL6 into the striatum of naive mice. Others have shown that IFN $\gamma$ was the only of many growth factors tested to increase astroglial CNTF in culture (Carroll et al., 1993), and IL6 increased CNTF in dorsal root ganglion culture (Shuto et al.,
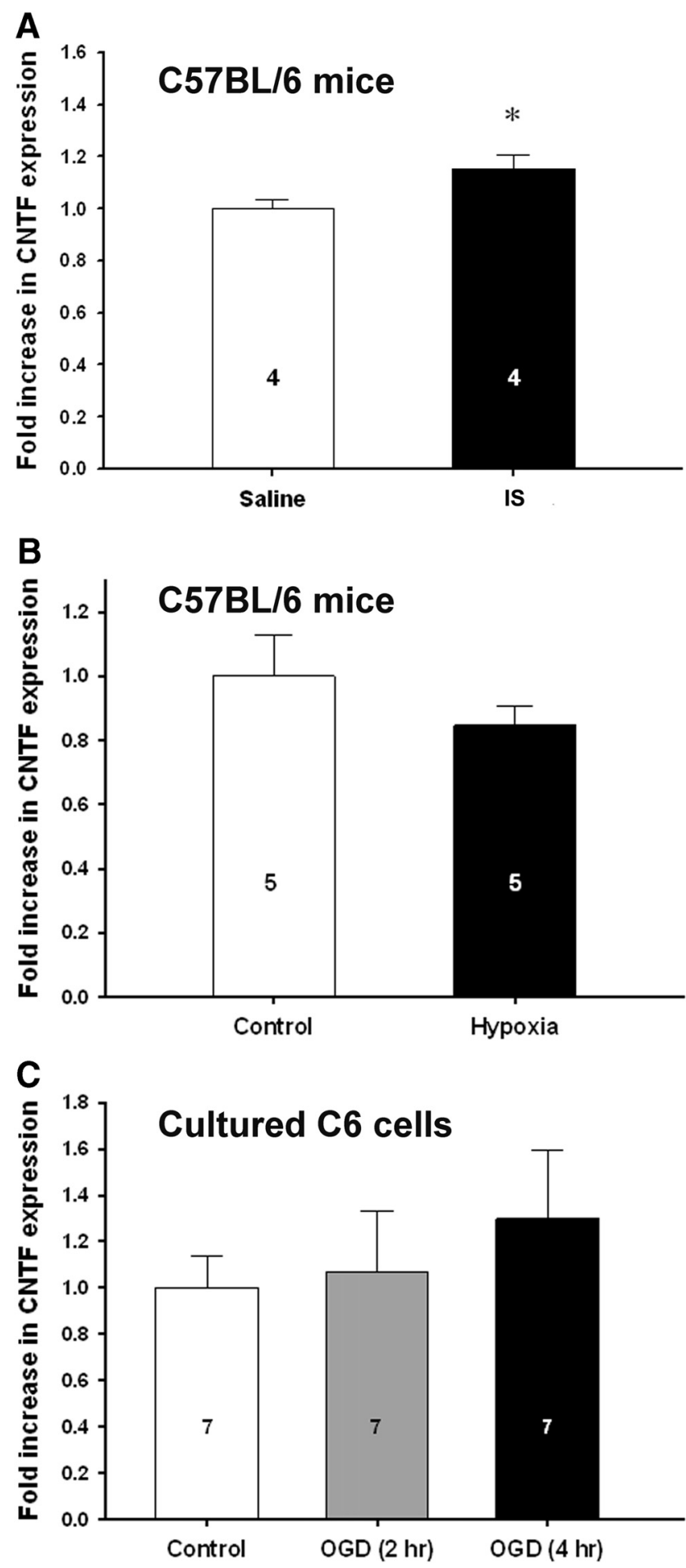

Figure 6. Ischemic conditions minimally affect CNTF expression. $\boldsymbol{A}$, CNTF expression after an intrastriatal injection of a solution that mimics ischemic metabolic conditions into naive C57BL/6 mice has only a small effect after $1 \mathrm{~h}$ compared to MCAO, which increases CNTF by twofold at $1 \mathrm{~h}$ (Fig. 1A). B, Severe whole-body hypoxia from 7 to $5 \%$ on C57BL/6 mice has no significant effect on CNTF expression. $\boldsymbol{C}$, In astrocyte cultures, oxygen-glucose deprivation, a model for stroke, has no effect on cultured $\mathrm{C} 6$ glioma cells. Group sizes are indicated in the columns. Data are shown as the average + SEM. ${ }^{*} p<0.05$.

2001). Both are increased after stroke (Clark et al., 1999; de Bilbao et al., 2009). Here, IFN $\gamma$ had no effect, and IL6 increased CNTF in the striatum only by twofold after $24 \mathrm{~h}$ (Fig. $7 A$ ), compared to the more than sevenfold increase seen after MCAO. Stem cell factor 
A

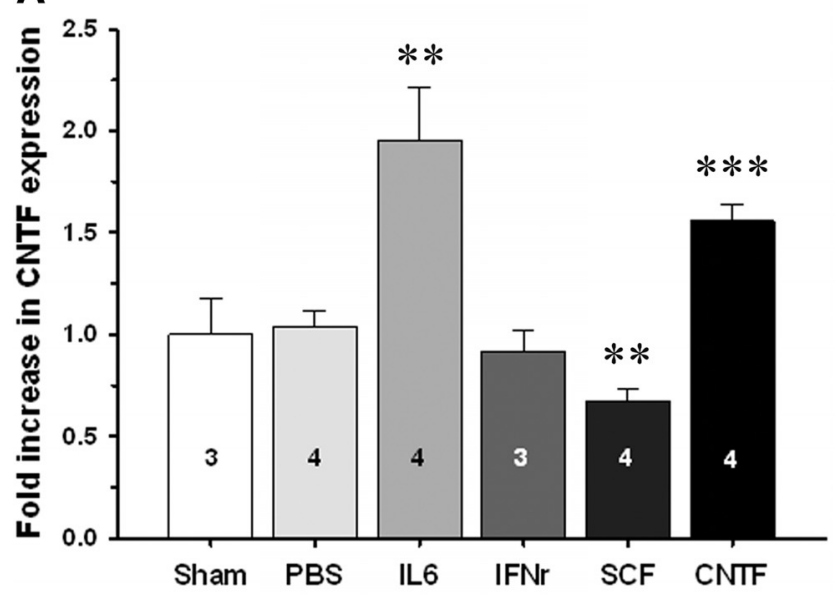

B

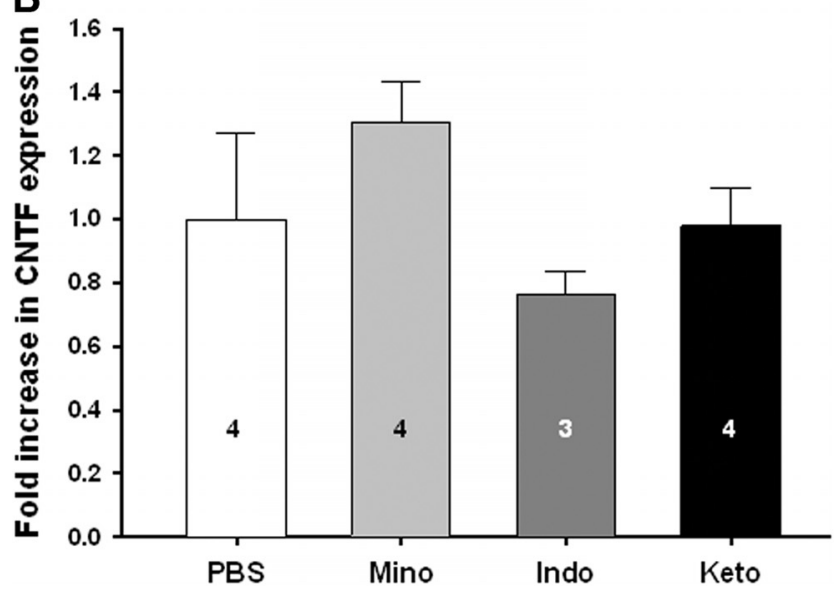

Figure 7. Inflammation does not or minimally affects CNTF expression in C57BL/6 mice. $\boldsymbol{A}$, Intrastriatal injection of the proinflammatory cytokines IL6 or IFN $\gamma$ in naive mice induces a much smaller increase or does not increase CNTF expression after $24 \mathrm{~h}$, respectively, compared to the sevenfold increase seen with MCAO (Fig. 1). SCF, which others have shown increases CNTF in vitro, has an inhibitory effect. Interestingly, CNTF appears to have autocrine functions as shown by its positive effects on CNTF expression. $\boldsymbol{B}$, Systemic administration of three different anti-inflammatory drugs, minocycline (Mino), indomethacin (Indo), and ketoprofen (Keto), compared to PBS control injections, from $1 \mathrm{~d}$ after MCAO until $7 \mathrm{~d}$, does not affect the MCAOinduced increases in CNTF expression in C57BL/6 mice. Group sizes are indicated in the columns. Data are shown as the average + SEM. ${ }^{* *} p<0.01 ;{ }^{* * *} p<0.001$.

(SCF) has been shown to increase CNTF expression and to have anti-inflammatory properties in cultured microglia (Zhang and Fedoroff, 1998). It is increased in the penumbra of traumatic brain injury (Sun et al., 2004), where CNTF also increases (Ip, 1998). However, SCF did not increase CNTF expression $24 \mathrm{~h}$ after injection into the naive striatum (Fig. 7A). CNTF itself has been shown to activate microglia (Hagg et al., 1993). A single injection of CNTF in the striatum of naive mice caused an increase of $1.56 \pm 0.07$-fold $(p<0.001)$ after $24 \mathrm{~h}$ (Fig. $7 A)$, suggesting the existence of autocrine regulation mechanism to increase CNTF expression via the gp130 receptor complex. To test whether inflammation contributed to the progressive increase over the first week after MCAO, mice were treated with daily intraperitoneal injections with anti-inflammatory drugs from $1 \mathrm{~d}$ to $7 \mathrm{~d}$ following MCAO. We started the treatment $24 \mathrm{~h}$ after the MCAO to reduce the potential impact of the neuroprotective actions of these antiinflammatory drugs, i.e., to reduce the confounding impact of less neuronal cell death, which would be expected to lead to less of an increase in CNTF levels. Minocycline, which is known to reduce microglial activation and inflammation (Yrjänheikki et al., 1999), and the known anti-inflammatory drugs indomethacine and ketoprofen had no significant effect on the CNTF levels following MCAO compared to saline controls (Fig. 7B).

\section{Increased CNTF plays a protective role following MCAO}

We were interested in understanding what the pathophysiological role of the increased striatal CNTF following MCAO might be. In light of the neuroprotective effects of CNTF treatments, we set out to determine whether the endogenous CNTF response would contribute to improved outcomes. A 30 min MCAO caused a substantial injury to the striatum and overlying cortex in wildtype mice as shown by cresyl violet-stained sections 2 weeks after injury (Fig. $8 A$ ). In $C N T F-/-$ mice, the injury appeared to be larger (Fig. $8 B$ ), which was confirmed by quantification of the injured area (Fig. $8 E$ ). The area of the normal side of the brain was not different between the genotypes (data not shown). GFAP-stained sections also showed a clear demarcated region of infarcted, GFAP-negative tissue that was larger in CNTF-/mice (Fig. 8C-E). The CNTF measurements in this study were all from the striatum, and we separately analyzed the injury in the striatum. CNTF-/- mice also had a larger area of injury within the striatum as measured by the absence of GFAP staining (Fig. $8 C-E)$. CNTF has been shown to play a role in gliosis after spinal cord injury (Ishii et al., 2006). However, there was no significant difference in the area occupied by the GFAP-stained astroglial processes within the striatum, whether measured by the total number of pixels or recalculated as a percentage of the surviving striatal tissue (as identified by GFAP staining; Fig. 8 E). Moreover, the increase in GFAP seen in the neighboring septum was similar between the $\mathrm{CNTF}-/-$ and wild-type mice (data not shown). Together, these data suggest that the increase in striatal CNTF expression following MCAO is protective for both neurons and astrocytes.

\section{Discussion}

Our data suggest that pathological disruption of neuronal interactions with astrocytes leads to rapid and large increases in CNTF expression, which has a cell-protective role. Conversely, normal neuron-astrocyte interaction greatly suppresses astrocytic CNTF expression in vivo and in astrocytes in cocultures, as also shown by Rudge et al. (1994). The contact-mediated nature of the normal repression is supported by the finding that CNTF increased in vitro after mild trypsinization, which would disrupt proteins on the cell surfaces. The similarity in the effects of the pure striatal neuronal quinolinic acid injury in adult mice and the MCAO also supports the idea that loss of neuronal contact is sufficient to induce CNTF in vivo. Moreover, the most rapid increase in CNTF was seen during the acute postischemic phase. Once the neurons are lost at $1 \mathrm{~d}$, the CNTF increase slows down in the following days. Conversely, soluble neuronal molecules did not affect CNTF expression, as shown with neuronal cocultures in a transwell system or neuronal-conditioned media. The MCAO most likely did not increase CNTF by the expected changes in neurotransmitter levels following the injury, as suggested by the lack of an effect of glutamate or GABA on CNTF expression in cultured astrocytes. CNTF regulation by glutamate seems even less likely since the potent NMDA receptor antagonist MK-801 had no effect in vitro. CNTF regulation might be unique compared to other neurotrophic factors, including BDNF and NGF, which are regulated by glutamate and GABA (Zafra et al., 1991, 1992; Wu et al., 2004). If correct, this suggests that CNTF plays a unique role 
in the CNS and may enable the development of pharmacological agents that predominantly regulate $\mathrm{CNTF}$. The molecular mechanisms underlying the normal neuronal contact-mediated CNTF repression in astrocytes in vivo remain to be determined. Our finding in vitro that blocking RGD peptide increases CNTF suggests that it is normally repressed by integrins. Those data also suggest that the increased CNTF expression is dependent on transcription and thus is regulated by intracellular signaling pathways. This is consistent with the very rapid nature of the increase following MCAO in vivo, which would be difficult to explain with posttranscriptional mechanisms, given that CNTF mRNA has a half-life of $7 \mathrm{~h}$.

MCAO is an ischemic injury causing both anoxia/hypoxia and lack of glucose. However, these metabolic effects most likely did not affect the striatal CNTF levels, as intrastriatal injection of a solution that mimics the metabolic conditions measured within an ischemic injury (Yao et al., 2007) or severe whole-body hypoxia was without effect. Moreover, OGD, an accepted model of ischemic stroke (Véga et al., 2006), had no effect on CNTF levels in a glial cell line. We considered whether inflammation might regulate CNTF, as it is a known consequence of MCAO injury (Dirnagl et al., 1999) and can activate astrocytes (Sofroniew, 2005). However, intrastriatal injection of the proinflammatory cytokines IL6 and IFN $\gamma$ in naive mice had a small effect or no effect, respectively, on CNTF expression compared to MCAO at $24 \mathrm{~h}$. The increase in CNTF after the first day also does not seem to be regulated by inflammation, as three different anti-inflammatory drugs did not affect the levels of MCAO-induced CNTF at 1 week. The slower progressive increase is most likely not directly regulated by loss of neuronal contact, as it occurred after the neurons had already died. Autocrine CNTF might contribute to this progressive nature, given our finding that intrastriatal CNTF injections in naive mice increased CNTF expression. Also, CNTF treatment enhances retinal ganglion cell regeneration in part via stimulating endogenous CNTF (Müller et al., 2009).

The rapid increase in CNTF expression following MCAO is consistent with the idea that it is an injury factor important for regulation of biological processes during the acute injury phase. The later apparent slower rise in CNTF may be related to repair. The CNTF distribution data following stroke would be consistent with the idea that the rescue response is diffuse in areas that survive, whereas the repair response is in the penumbra, perhaps related to blood-brain barrier repair. CNTF is most likely not involved in the reactive gliosis given the similar glial activation seen in $\mathrm{CNTF}-/$ - and their wild-type littermates fol-
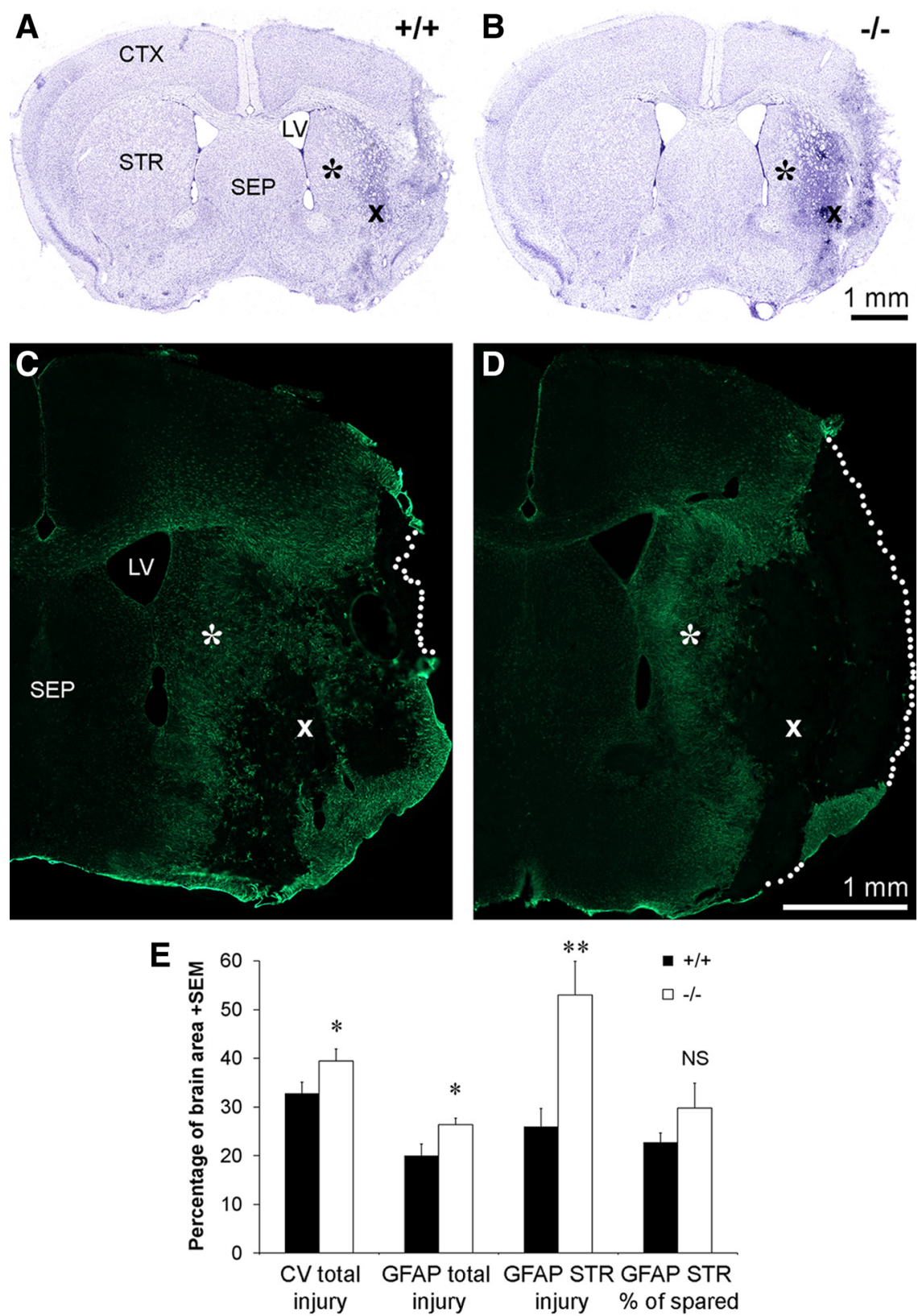

Figure 8. CNTF-/ - mice have larger injuries following MCAO. $A, B$, Compared to wild-type mice $(A)$, CNTF- / - littermates $(B)$ have more extensive loss of neurons $14 \mathrm{~d}$ following MCA0, as shown in cresyl violet-stained sections. Note the differences in the spared striatal tissue (asterisks) and the degenerated striatal tissue $(X)$ between the genotypes. $\boldsymbol{C}, \boldsymbol{D}$, Adjacent sections stained for GFAP show the concurrent loss of astrocytes in the injury core. The stippled lines indicate the border of the brain sections. Symbols ( ${ }^{*}$ and $X$ ) are in the exact same positions as in $\boldsymbol{A}$ and $\boldsymbol{B}$. (TX, Cerebral cortex; LV, lateral ventricle; SEP, septum; STR, striatum. $\boldsymbol{E}$, Quantification of the histological sections confirm that (NTF- - - mice have a larger injury area as measured by the area of loss of neurons in cresyl violet-stained sections (left pair of columns) or of loss of GFAP staining (second pair). Injury to the striatum, as measured in GFAP-stained sections, which allow clear demarcation of the GFAP-negative area, showed larger differences (third pair of columns). The percentage within the spared tissue of GFAP-stained pixels was not significantly different between the genotypes, suggesting that glial activation is not affected by the lack of CNTF (right pair of columns). The group size is four each. Data are shown as the average + SEM. NS, Not significant; ${ }^{*} p<0.05 ;{ }^{* *} p<0.01$.

lowing MCAO (present study), optic nerve injury (Martin et al., 2003), and spinal cord injury (T. Hagg, unpublished observation). In fact, the time course of astrocyte activation in $\mathrm{CNTF}-/-$ mice was even accelerated following optic nerve injury (Martin et al., 2003), raising the possibility that CNTF plays an inhibitory feedback role in glial reactivity. The neuronal contact-mediated inhibition in astrocytes raises the possibility that CNTF plays an important reciprocal role in this close inter- 
cellular relationship and that the injury-induced CNTF primarily serves to protect neurons. In other words, the rapid glial CNTF response might be an indication of a glial sensor system for neuronal stress or pathological changes that is exaggerated in MCAO but might also play a role in other more slowly progressing disorders.

The MCAO is known to induce rapid increases in both CNTF mRNA and protein (Hu et al., 1997; Park et al., 2000; Leibinger et al., 2009). CNTF is most likely released from the astrocytes and biologically active, as suggested by the neuroprotective effects seen in the wild-type mice compared to their $C N T F-/-$ littermates. Rescue experiments by injecting CNTF in $\mathrm{CNTF}-/-$ mice would solidify whether endogenous CNTF is neuroprotective or whether developmental differences in $C N T F-/-$ mice predisposed them to worse ischemic injuries. On the other hand, the striatal neurons are directly responsive to CNTF, as suggested by their expression of the specific CNTF $\alpha$ receptor (Ip et al., 1993b; Emsley and Hagg, 2003) and the findings that CNTF treatments can rescue them in vitro (Petersén and Brundin, 1999) and in vivo (Anderson et al., 1996; Emerich et al., 1997; Zala et al., 2004). CNTF treatments can also lead to enhanced recovery following ischemic stroke in rats (Kumon et al., 1996). Alternatively or additionally, endogenous CNTF could reduce degeneration following MCAO by enhancing astroglial glutamate uptake to reduce excitotoxicity (Escartin et al., 2006; Beurrier et al., 2010). CNTF expression is normally very low in the CNS, including the striatum (Stockli et al., 1989), and the rapid increase combined with its neuroprotective effects suggests that its main role might be as a lesion factor. Based on the morphology of the injury, which contains a central degenerated core after ischemic stroke, the protection most likely preserves penumbral neuronal tissue. Whereas the core dies by necrosis, the penumbral neuronal loss is characterized by apoptosis (Ferrer and Planas, 2003) and progresses over several hours following stroke (Heiss and Graf, 1994; Lo, 2008). This suggests that the initial increase in endogenous CNTF levels is quick enough to rescue these penumbral neurons, but not quick enough to rescue those more severely injured ones within the core. It is also possible that apoptosis but not necrosis can be counteracted by CNTF. However, CNTF treatments can rescue neurons against NMDA toxicity (Anderson et al., 1996; Emerich et al., 1997), which is one of the main mechanisms by which the ischemic core neurons die (Lipton, 2006; Rossi et al., 2007). Interestingly, the injury core is devoid of GFAP-positive astrocytes, as also shown by others who found fluorojade staining in penumbral astrocytes (Butler et al., 2002), suggesting that the astrocytes also degenerate after ischemia. Our $C N T F-/-$ mouse data suggest that their enhanced astrocyte loss following MCAO is caused by the lack of CNTF. Astrocytes express CNTF $\alpha$ receptors (Emsley and Hagg, 2003; Choi et al., 2004) but so far have not been shown to be dependent on CNTF for their survival under pathological conditions. The loss of CNTF-producing astrocytes in the core of the injury might explain why the core neurons degenerate.

The question arises whether CNTF's role as a highly regulatable protein might also play a physiological role in the normal CNS as a rapid responder to and controller of neuronal function. Astrocytes are now viewed as the third component of the synapse to regulate neurotransmission (Barker and Ullian, 2010; Freeman, 2010; Giaume et al., 2010; Panatier et al., 2011). Thus, it is not surprising that CNTF can enhance normal synaptic function (Stoop and Poo, 1996; Nai et al., 2010) and reduce synaptic degeneration and cognitive defects in a mouse Alzheimer model (Garcia et al., 2010). In cultured Xenopus motor neurons, CNTF application to the soma potentiates synaptic function within 10 $\mathrm{min}$, and a bit more slowly when applied to the neuromuscular synapse (Stoop and Poo, 1995). This suggests that CNTF can modulate somatic control of synaptic function on a relatively short time scale. Its highly regulatable nature by neuron-astrocyte contact would make CNTF a very adaptable modulator of synaptic function. CNTF could affect normal transmission directly via neuronal receptors on the soma or synapse (Stoop and Poo, 1995) or by modulating astroglial glutamate transporters (Escartin et al., 2006).

Finally, we propose that a better understanding of the mechanisms that regulate CNTF expression would help us to more rationally design pharmacological treatments to boost the natural neuroprotective response to injury as well as its normal physiological roles in synaptic transmission. For example, further increasing or accelerating the endogenous increase in response to ischemia might help recovery, given the finding that exogenous CNTF can do the same (Kumon et al., 1996). CNTF is a good drug target, as it is almost exclusively produced in nervous system. Thus, systemic drugs that increase its production would help to circumvent CNTF's poor bioavailability to the CNS and peripheral side effects when given systemically (Thoenen and Sendtner, 2002).

\section{References}

Anderson KD, Panayotatos N, Corcoran TL, Lindsay RM, Wiegand SJ (1996) Ciliary neurotrophic factor protects striatal output neurons in an animal model of Huntington disease. Proc Natl Acad Sci USA 93:7346-7351.

Asada H, Ip NY, Pan L, Razack N, Parfitt MM, Plunkett RJ (1995) Time course of ciliary neurotrophic factor mRNA expression is coincident with the presence of protoplasmic astrocytes in traumatized rat striatum. J Neurosci Res 40:22-30.

Barker AJ, Ullian EM (2010) Astrocytes and synaptic plasticity. Neuroscientist 16:40-50.

Beurrier C, Faideau M, Bennouar KE, Escartin C, Kerkerian-Le Goff L, Bonvento G, Gubellini P (2010) Ciliary neurotrophic factor protects striatal neurons against excitotoxicity by enhancing glial glutamate uptake. PLoS One 5:e8550.

Butler TL, Kassed CA, Sanberg PR, Willing AE, Pennypacker KR (2002) Neurodegeneration in the rat hippocampus and striatum after middle cerebral artery occlusion. Brain Res 929:252-260.

Carroll P, Sendtner M, Meyer M, Thoenen H (1993) Rat ciliary neurotrophic factor (CNTF): gene structure and regulation of mRNA levels in glial cell cultures. Glia 9:176-187.

Choi JS, Kim SY, Park HJ, Cha JH, Choi YS, Chung JW, Chun MH, Lee MY (2004) Differential regulation of ciliary neurotrophic factor and its receptor in the rat hippocampus in response to kainic acid-induced excitotoxicity. Mol Cells 17:292-296.

Clark WM, Rinker LG, Lessov NS, Hazel K, Eckenstein F (1999) Time course of IL-6 expression in experimental CNS ischemia. Neurol Res 21:287-292.

de Bilbao F, Arsenijevic D, Moll T, Garcia-Gabay I, Vallet P, Langhans W, Giannakopoulos P (2009) In vivo over-expression of interleukin-10 increases resistance to focal brain ischemia in mice. J Neurochem 110:12-22.

Dirnagl U, Iadecola C, Moskowitz MA (1999) Pathobiology of ischaemic stroke: an integrated view. Trends Neurosci 22:391-397.

Droppelmann CA, Gutiérrez J, Vial C, Brandan E (2009) Matrix metalloproteinase-2-deficient fibroblasts exhibit an alteration in the fibrotic response to connective tissue growth factor/CCN2 because of an increase in the levels of endogenous fibronectin. J Biol Chem 284:13551-13561.

Emerich DF, Thanos CG (2008) NT-501: an ophthalmic implant of polymer-encapsulated ciliary neurotrophic factor-producing cells. Curr Opin Mol Ther 10:506-515.

Emerich DF, Winn SR, Hantraye PM, Peschanski M, Chen EY, Chu Y, McDermott P, Baetge EE, Kordower JH (1997) Protective effect of encap- 
sulated cells producing neurotrophic factor CNTF in a monkey model of Huntington's disease. Nature 386:395-399.

Emsley JG, Hagg T (2003) Endogenous and exogenous ciliary neurotrophic factor enhances forebrain neurogenesis in adult mice. Exp Neurol 183:298-310.

Escartin C, Brouillet E, Gubellini P, Trioulier Y, Jacquard C, Smadja C, Knott GW, Kerkerian-Le Goff L, Déglon N, Hantraye P, Bonvento G (2006) Ciliary neurotrophic factor activates astrocytes, redistributes their glutamate transporters GLAST and GLT-1 to raft microdomains, and improves glutamate handling in vivo. J Neurosci 26:5978-5989.

Ferrer I, Planas AM (2003) Signaling of cell death and cell survival following focal cerebral ischemia: life and death struggle in the penumbra. J Neuropathol Exp Neurol 62:329-339.

Freeman MR (2010) Specification and morphogenesis of astrocytes. Science 330:774-778.

Garcia P, Youssef I, Utvik JK, Florent-BéchardS, Barthélémy V, MalaplateArmand C, Kriem B, Stenger C, Koziel V, Olivier JL, Escanye MC, Hanse M, Allouche A, Desbène C, Yen FT, Bjerkvig R, Oster T, Niclou SP, Pillot T (2010) Ciliary neurotrophic factor cell-based delivery prevents synaptic impairment and improves memory in mouse models of Alzheimer's disease. J Neurosci 30:7516-7527.

Giaume C, Koulakoff A, Roux L, Holcman D, Rouach N (2010) Astroglial networks: a step further in neuroglial and gliovascular interactions. Nat Rev Neurosci 11:87-99.

Goldberg MP, Choi DW (1993) Combined oxygen and glucose deprivation in cortical cell culture: calcium-dependent and calcium-independent mechanisms of neuronal injury. J Neurosci 13:3510-3524.

Hagg T, Varon S (1993) Ciliary neurotrophic factor prevents degeneration of adult rat substantia nigra dopaminergic neurons in vivo. Proc Natl Acad Sci U S A 90:6315-6319.

Hagg T, Quon D, Higaki J, Varon S (1992) Ciliary neurotrophic factor prevents neuronal degeneration and promotes low affinity NGF receptor expression in the adult rat CNS. Neuron 8:145-158.

Hagg T, Varon S, Louis JC (1993) Ciliary neurotrophic factor (CNTF) promotes low-affinity nerve growth factor receptor and CD4 expression by rat CNS microglia. J Neuroimmunol 48:177-187.

Heiss WD, Graf R (1994) The ischemic penumbra. Curr Opin Neurol 7:11-19.

Hu J, Saito T, Abe K, Deguchi T (1997) Increase of ciliary neurotrophic factor (CNTF) in the ischemic rat brain as determined by a sensitive enzyme-linked immunoassay. Neurol Res 19:593-598.

Ip NY (1998) The neurotrophins and neuropoietic cytokines: two families of growth factors acting on neural and hematopoietic cells. Ann N Y Acad Sci 840:97-106.

Ip NY, Wiegand SJ, Morse J, Rudge JS (1993a) Injury-induced regulation of ciliary neurotrophic factor mRNA in the adult rat brain. Eur J Neurosci 5:25-33.

Ip NY, McClain J, Barrezueta NX, Aldrich TH, Pan L, Li Y, Wiegand SJ, Friedman B, Davis S, Yancopoulos GD (1993b) The alpha component of the CNTF receptor is required for signaling and defines potential CNTF targets in the adult and during development. Neuron 10:89-102.

Ishii K, Nakamura M, Dai H, Finn TP, Okano H, Toyama Y, Bregman BS (2006) Neutralization of ciliary neurotrophic factor reduces astrocyte production from transplanted neural stem cells and promotes regeneration of corticospinal tract fibers in spinal cord injury. J Neurosci Res 84:1669-1681.

Kumon Y, Sakaki S, Watanabe H, Nakano K, Ohta S, Matsuda S, Yoshimura H, Sakanaka M (1996) Ciliary neurotrophic factor attenuates spatial cognition impairment, cortical infarction and thalamic degeneration in spontaneously hypertensive rats with focal cerebral ischemia. Neurosci Lett 206:141-144.

Leibinger M, Müller A, Andreadaki A, Hauk TG, Kirsch M, Fischer D (2009) Neuroprotective and axon growth-promoting effects following inflammatory stimulation on mature retinal ganglion cells in mice depend on ciliary neurotrophic factor and leukemia inhibitory factor. J Neurosci 29:14334-14341.

Lin TN, Wang PY, Chi SI, Kuo JS (1998) Differential regulation of ciliary neurotrophic factor (CNTF) and CNTF receptor alpha (CNTFR alpha) expression following focal cerebral ischemia. Mol Brain Res 55:71-80.

Linker RA, Mäurer M, Gaupp S, Martini R, Holtmann B, Giess R, Rieckmann P, Lassmann H, Toyka KV, Sendtner M, Gold R (2002) CNTF is a major protective factor in demyelinating CNS disease: a neurotrophic cytokine as modulator in neuroinflammation. Nat Med 8:620-624.

Lipton SA (2006) NMDA receptors, glial cells, and clinical medicine. Neuron 50:9-11.

Lo EH (2008) A new penumbra: transitioning from injury into repair after stroke. Nat Med 14:497-500.

Louis JC, Magal E, Takayama S, Varon S (1993) CNTF protection of oligodendrocytes against natural and tumor necrosis factor-induced death. Science 259:689-692.

Martin A, Hofmann HD, Kirsch M (2003) Glial reactivity in ciliary neurotrophic factor-deficient mice after optic nerve lesion. J Neurosci 23:5416-5424.

Meyer V, Unsicker K (1994) Cell density and exogenous CNTF affect CNTF mRNA levels in glial cell cultures. Neuroreport 5:1946-1948.

Mitsumoto H, Ikeda K, Holmlund T, Greene T, Cedarbaum JM, Wong V, Lindsay RM (1994) The effects of ciliary neurotrophic factor on motor dysfunction in wobbler mouse motor neuron disease. Ann Neurol $36: 142-148$

Müller A, Hauk TG, Leibinger M, Marienfeld R, Fischer D (2009) Exogenous CNTF stimulates axon regeneration of retinal ganglion cells partially via endogenous CNTF. Mol Cell Neurosci 41:233-246.

Nagao H, Matsuoka I, Kurihara K (1995) Effects of adenylyl cyclase-linked neuropeptides on the expression of ciliary neurotrophic factor-mRNA in cultured astrocytes. FEBS Lett 362:75-79.

Nai Q, Wang X, Jin Y, Sun D, Li M, Hu B, Zhang X (2010) Ciliary neurotrophic factor enhances nicotinic synaptic transmission in sympathetic neurons. J Neurosci Res 88:887-895.

Panatier A, Vallée J, Haber M, Murai KK, Lacaille JC, Robitaille R (2011) Astrocytes are endogenous regulators of basal transmission at central synapses. Cell 146:785-798.

Panetti TS, McKeown-Longo PJ (1993) The alpha v beta 5 integrin receptor regulates receptor-mediated endocytosis of vitronectin. J Biol Chem 268:11492-11495.

Park CK, Ju WK, Hofmann HD, Kirsch M, Ki Kang J, Chun MH, Lee MY (2000) Differential regulation of ciliary neurotrophic factor and its receptor in the rat hippocampus following transient global ischemia. Brain Res 861:345-353.

Petersén A, Brundin P (1999) Effects of ciliary neurotrophic factor on excitotoxicity and calcium-ionophore A23187-induced cell death in cultured embryonic striatal neurons. Exp Neurol 160:402-412.

Pinardi G, Sierralta F, Miranda HF (2003) Atropine reverses the antinociception of nonsteroidal anti-inflammatory drugs in the tail-flick test of mice. Pharmacol Biochem Behav 74:603-608.

Pun S, Santos AF, Saxena S, Xu L, Caroni P (2006) Selective vulnerability and pruning of phasic motoneuron axons in motoneuron disease alleviated by CNTF. Nat Neurosci 9:408-419.

Rossi DJ, Brady JD, Mohr C (2007) Astrocyte metabolism and signaling during brain ischemia. Nat Neurosci 10:1377-1386.

Rudge JS, Morrissey D, Lindsay RM, Pasnikowski EM (1994) Regulation of ciliary neurotrophic factor in cultured rat hippocampal astrocytes. Eur J Neurosci 6:218-229.

Sagot Y, Tan SA, Baetge E, Schmalbruch H, Kato AC, Aebischer P (1995) Polymer encapsulated cell lines genetically engineered to release ciliary neurotrophic factor can slow down progressive motor neuronopathy in the mouse. Eur J Neurosci 7:1313-1322.

Schauwecker PE (2005) Susceptibility to excitotoxic and metabolic striatal neurodegeneration in the mouse is genotype dependent. Brain Res 1040:112-120.

Shuto T, Horie H, Hikawa N, Sango K, Tokashiki A, Murata H, Yamamoto I, Ishikawa Y (2001) IL-6 up-regulates CNTF mRNA expression and enhances neurite regeneration. Neuroreport 12:1081-1085.

Sieving PA, Caruso RC, Tao W, Coleman HR, Thompson DJ, Fullmer KR, Bush RA (2006) Ciliary neurotrophic factor (CNTF) for human retinal degeneration: phase I trial of CNTF delivered by encapsulated cell intraocular implants. Proc Natl Acad Sci U S A 103:3896-3901.

Simon CM, Jablonka S, Ruiz R, Tabares L, Sendtner M (2010) Ciliary neurotrophic factor-induced sprouting preserves motor function in a mouse model of mild spinal muscular atrophy. Hum Mol Genet 19:973-986.

Sofroniew MV (2005) Reactive astrocytes in neural repair and protection. Neuroscientist 11:400-407.

Stöckli KA, Lottspeich F, Sendtner M, Masiakowski P, Carroll P, Götz R, 
Lindholm D, Thoenen H (1989) Molecular cloning, expression and regional distribution of rat ciliary neurotrophic factor. Nature 342:920-923.

Stoop R, Poo MM (1995) Potentiation of transmitter release by ciliary neurotrophic factor requires somatic signaling. Science 267:695-699.

Stoop R, Poo MM (1996) Synaptic modulation by neurotrophic factors: differential and synergistic effects of brain-derived neurotrophic factor and ciliary neurotrophic factor. J Neurosci 16:3256-3264.

Sun L, Lee J, Fine HA (2004) Neuronally expressed stem cell factor induces neural stem cell migration to areas of brain injury. J Clin Invest 113:1364-1374.

Thoenen H, Sendtner M (2002) Neurotrophins: from enthusiastic expectations through sobering experiences to rational therapeutic approaches. Nat Neurosci 5 [Suppl]:1046-1050.

Valenzuela DM, Murphy AJ, Frendewey D, Gale NW, Economides AN, Auerbach W, Poueymirou WT, Adams NC, Rojas J, Yasenchak J, Chernomorsky R, Boucher M, Elsasser AL, Esau L, Zheng J, Griffiths JA, Wang X, Su H, Xue Y, Dominguez MG, et al. (2003) High-throughput engineering of the mouse genome coupled with high-resolution expression analysis. Nat Biotechnol 21:652-659.

Véga CR, Sachleben L Jr, Gozal D, Gozal E (2006) Differential metabolic adaptation to acute and long-term hypoxia in rat primary cortical astrocytes. J Neurochem 97:872-883.

Veltkamp R, Rajapakse N, Robins G, Puskar M, Shimizu K, Busija D (2002) Transient focal ischemia increases endothelial nitric oxide synthase in cerebral blood vessels. Stroke 33:2704-2710.

Wang X, Yue TL, Young PR, Barone FC, Feuerstein GZ (1995) Expression of interleukin-6, c-fos, and zif268 mRNAs in rat ischemic cortex. J Cereb Blood Flow Metab 15:166-171.

Weng YC, Kriz J (2007) Differential neuroprotective effects of a minocycline-based drug cocktail in transient and permanent focal cerebral ischemia. Exp Neurol 204:433-442.

Wu H, Friedman WJ, Dreyfus CF (2004) Differential regulation of neurotrophin expression in basal forebrain astrocytes by neuronal signals. J Neurosci Res 76:76-85.

Yang P, Arnold SA, Habas A, Hetman M, Hagg T (2008) Ciliary neurotrophic factor mediates dopamine D2 receptor-induced CNS neurogenesis in adult mice. J Neurosci 28:2231-2241.

Yao H, Shu Y, Wang J, Brinkman BC, Haddad GG (2007) Factors influencing cell fate in the infarct rim. J Neurochem 100:1224-1233.

Yrjänheikki J, Tikka T, Keinänen R, Goldsteins G, Chan PH, Koistinaho J (1999) A tetracycline derivative, minocycline, reduces inflammation and protects against focal cerebral ischemia with a wide therapeutic window. Proc Natl Acad Sci U S A 96:13496-13500.

Zafra F, Castrén E, Thoenen H, Lindholm D (1991) Interplay between glutamate and gamma-aminobutyric acid transmitter systems in the physiological regulation of brain-derived neurotrophic factor and nerve growth factor synthesis in hippocampal neurons. Proc Natl Acad Sci U S A 88:10037-10041.

Zafra F, Lindholm D, Castrén E, Hartikka J, Thoenen H (1992) Regulation of brain-derived neurotrophic factor and nerve growth factor mRNA in primary cultures of hippocampal neurons and astrocytes. J Neurosci 12:4793-4799.

Zala D, Bensadoun JC, Pereira de Almeida L, Leavitt BR, Gutekunst CA, Aebischer P, Hayden MR, Déglon N (2004) Long-term lentiviralmediated expression of ciliary neurotrophic factor in the striatum of Huntington's disease transgenic mice. Exp Neurol 185:26-35.

Zhang SC, Fedoroff S (1998) Modulation of microglia by stem cell factor. J Neurosci Res 53:29-37.

Zhang SX, Miller JJ, Gozal D, Wang Y (2004) Whole-body hypoxic preconditioning protects mice against acute hypoxia by improving lung function. J Appl Physiol 96:392-397. 